\title{
Tomasz Ciesielski
}

Uniwersytet Opolski

e-mail: ciesielski2@wp.pl

telefon: +48605361 693

DOI: $10.15290 / \mathrm{mhi} .2016 .15 .01 .06$

\section{Artykuły wojenne dla artylerii koronnej Augusta III z 1737 r.}

\author{
SUMMARY \\ Articles of war for the artillery of Augustus III from 1737
}

During the reigns of Augustus II and Augustus III (both Polish) - the Lithuanian Commonwealth's armies were modernized. As early as during the Great Northern War the armies were equipped with relatively modern military devices, and within the following decades efforts were made to keep the equipment in line with European standards. As far as the financial and organizational aspects were concerned, the most significant were the reforms of the Silent Sejm from 1717. Moreover, it was signalled that the military law should be thoroughly modernized by means of developing general and detailed codes determining the rules of military service and principles of everyday life for the soldiers of both Commonwealth's armies. Although a few, or perhaps several drafts of such codes were developed, what finally happened was that the military law applicable in 1753-1755 was codified (three codes, two of which were prepared for printing by Samuel Brodowski), and foremostly, three new normative acts regulating the principles of organization and discipline in the Commonwealth's army were issued. One of them was authored by Augustus II, who in 1698 announced new Military Articles. His son and heir to the Commonwealth's throne, Augustus III made an attempt to modify those articles by means of issuing his own War Articles in 1749. However, it does not seem that they were widely adopted in the royal and Lithuanian armies or that they supplanted the articles of Augustus II. They shared the fate of an earlier attempt made by Augustus III in order to modify the applicable military law, i.e. the Articles for artillery issued in 1737. In fact, the only proof of their existence is the royal diploma establishing those articles stored in the National Archives in Cracow and reprinted in this article. I did not access any source materials confirming that the articles of Augustus III were presented to artillery officers in either royal or Lithuanian armies, or that they were ever applied in the court practice. From the preamble it may be concluded that the articles were published at the request of the head of the Polish artillery, Zygmunt Adolf Rybinski, and developed on the basis of the royal articles for artillery from the first half of 17th century. In fact, although there were numerous common elements with the articles issued by Władysław IV, their construction and number of paragraphs were different, and most importantly so were the definitions of disciplinary rules and the punishments catalogue. In fact, the articles of Augustus III were modelled upon the normative acts regulating the provisions of criminal law applicable in the Saxon army artillery. However, the obligations 
imposed upon the soldiers, the same as in the case of other military articles announced for the Commonwealth's army since the mid-16th century and by the 1780s: loyalty to the King and the Commonwealth; absolute obedience to the King and all army superiors along with following their orders; diligent fulfilment of duties, especially during watch and war time; taking good care of military equipment; modest and proper behaviour within stationing and accommodation sites. The articles also regulated the principles of concluding marriages, which was only possible upon obtaining permission from the superiors. The articles also strictly prohibited initiating riots, brawling among the soldiers, duelling, causing harm to the civilians, committing criminal offences, cowardice or desertion while facing the enemy, spying for the enemy and destroying public utility facilities along with mills, ploughs and bakery ovens both within the territory of their own and enemy countries. Failure to comply with the obligations and duties resulted in severe punishments, both financial and corporal, imprisonment combined with heavy physical work or even capital punishment.

Key words: Polish-Lithuanian Commonwealth, army, August III, military law.

Słowa kluczowe: Rzeczpospolita Obojga Narodów, armia, August III, prawo wojskowe.

W czasach panowania Augusta II i Augusta III dokonał się proces modernizacji obu armii Rzeczypospolitej Obojga Narodów. Jeszcze w okresie wielkiej wojny północnej przezbrojono wchodzące w ich skład oddziały autoramentu cudzoziemskiego w nowoczesną skałkową broń palną oraz pałasze i szable wzorowane na używanych w armii saskiej. W skali całych formacji, piechoty i dragonii, ujednolicono pod względem kroju umundurowanie - w poszczególnych regimentach różniło się barwą sukna kamizelek i wyłogów - obuwie (trzewiki i kamasze) oraz tzw. ledewerk (pasy, ładownice, tornistry). Wprowadzono też jako obowiązkowy sprzęt obozowy i wozy transportowe (choć nie występowały we wszystkich regimentach) ${ }^{1}$. W zakresie finansowym i organizacyjnym największe znaczenie miały reformy sejmu niemego z 1717 r. Wprowadziły one stałe budżety dla obu armii, do których dostosowano ich komputy, czyli liczebność wyrażoną w stawkach żołdowych (było ich więcej niż ludzi, gdyż podoficerowie i oficerowie pobierali odpowiednie do stopnia wielokrotności stawki żołnierskiej). Każdemu oddziałowi przypisano konkretne ziemie, powiaty i starostwa, z których podatki przeznaczono na ich utrzymanie. Utrzymano podział obu armii na artylerię oraz dwa autoramenty: cudzoziemski i narodowy. Ten ostatni tworzyły niewielkie chorągwie husarii, jazdy pancernej (Korona) lub

J. Wimmer, Wojsko Rzeczypospolitej w dobie wojny pótnocnej, Warszawa 1956, s. 147-169, 259, 449-451, 470-471; W. Dziewanowski, Zarys dziejów uzbrojenia w Polsce, Warszawa 1935, s. 127 n; M. Wagner, Zmiany w uzbrojeniu wojsk polskich na początku XVIII wieku, [w:] Technika a wojna X-XX w., red. P. Matusek, J. Piłatowicz, Siedlce 2000, s. 123-155; T. Ciesielski, Armia koronna w czasach Augusta III, Warszawa 2009, s. 445-486; idem, Wojsko litewskie w latach 1698-1709, [w:] Wojny pótnocne w XVI-XVIII wieku, red. B. Dybaś, A. Ziemlewska, Torun 2007, s. 177-178; T. Ciesielski, R. Sachs, Breslau als Lieferant für die königlich polnische Armee, [w:] Amator Scientiae. Festchrift für Dr. Peter Ohr, oprac. R. Sachs, Breslau 2003, s. 185-193; M. Siciński, Umundurowanie armii Wielkiego Księstwa Litewskiego w okresie panowania Augusta II i Augusta III Wettinów oraz panowania Stanisława Augusta do czasów reform Sejmu Wielkiego 1717-1791, „Studia do dziejów dawnego uzbrojenia i ubioru wojskowego”, cz. 13, Kraków 2011, s. 125-132. 
petyhorskiej (Wielkie Księstwo Litewskie), kawalerii lekkiej sformowanej na modłę kozacką czy tatarską, a także piechota typu węgierskiego lub janczarskiego. W skład autoramentu cudzoziemskiego wchodziły 300-1200-porcjowe regimenty piechoty i dragonii, a artyleria dzieliła się na sztab, korpus kanonierski i bombardierski (obsługa armat i moździerzy) oraz tzw. freikompanię, czyli samodzielną kompanię dragońską, piechoty lub o mieszanym składzie ${ }^{2}$. W trakcie reformowania armii na podstawie konstytucji sejmowych opracowano dla regimentów autoramentu cudzoziemskiego założenia tzw. regulamenów, czyli regulaminów organizacyjnych, w których opisano struktury organizacyjne oddziałów, ich skład osobowy oraz wyposażenie. Wspominano w nich o kwestiach dyscypliny i wyszkolenia żołnierzy, tak indywidualnego, jak i „zespołowego" - ale ogólnikowo, zapowiadając opracowanie regulaminów opisujących reguły służby i życia wszystkich żołnierzy obu armii Rzeczypospolitej ${ }^{3}$. I choć powstało kilka, może kilkanaście projektów takich regulaminów ${ }^{4}$, to ostatecznie skończyło się jedynie na sporządzeniu zbiorów obowiązującego prawa wojskowego w latach 1753-1755 (dwa przygotował do druku Samuel Brodowski) ${ }^{5}$, a przede wszystkim na ustanowieniu przez króla Augusta III Wettina dwóch nowych aktów normatywnych regulujących zasady organizacji i dyscypliny w wojsku Rzeczypospolitej: "Artykułów Wojskowych dla Artylerii Koronnej” z 1737 r. i „Artykułów Wojennych” wydanych w 1749 r.

W Rzeczypospolitej tytuły ,artykuły wojskowe” lub „artykuły wojenne” nadawano aktom normatywnym wydawanym początkowo przez rotmistrzów, a następnie przez hetmanów i królów, które określały podstawowe obowiązki służbowe żołnierzy oraz zasady organizacji i dyscypliny w wojsku. Były odpowiednikiem niemieckich "Artikelbrief”, francuskich „ordinances militares”, czy szwedzkich „kriegsartiklar”. W Koronie i Wielkim Księstwie Litewskim wydawane były, jak ustalił Karol Łopatecki, od pierwszych dekad XVI w. ${ }^{6}$ Początkowo miały „,charakter kontraktu zawiązywanego z żołnierzami, w świetle którego przyjmowali oni reguły wymierzania kar i zobowiązywali się do właściwego

2 T. Ciesielski, Armia koronna..., s. 19-112; idem, Armia Wielkiego Księstwa Litewskiego w latach 1717-1775, [w:] Studia z dziejów Wielkiego Księstwa Litewskiego (XVI-XVIII wieku), red. S. Górzyński i M. Nagielski, Warszawa 2104, s. 59-94 (w obu pracach wyliczona starsza literatura przedmiotu).

3 T. Ciesielski, Armia koronna..., s. 209-215; idem, Armia Wielkiego..., s. 73-85; V. Rakutis, Lietuvos kariuomenés organizacija reglamentuojantys dokumentai 1717-1775 m., „Karo archyvas”, t. 18, Vilnius 2003, s. $79-100$.

$4 \quad$ Projekty regulaminów służby dla regimentów piechoty i dragonii, Biblioteka Książąt Czartoryskich w Krakowie, 2630; Archiwum Narodowe w Krakowie (ANKr), Archiwum Podhoreckie (APodh), I, 120; II, 8, 32, 52 (s. 138-149), 172, 175, 183, 186, 229; Archiwum Państwowe w Poznaniu, Archiwum Antoniego Kossowskiego, 10. T. Ciesielski, Armia koronna..., s. 434-435.

5 T. Ciesielski, Samuel Brodowski - kodyfikator prawa wojskowego w czasach panowania Augusta III, [w:] Historia testis temporum, lux veritatis vita memoriae, nuntia vetustatis. Księga Jublieuszowa dedykowana Profesorowi Włodzimierzowi Kaczorowskiemu, red. E. Kozerska, M. Maciejewski, P. Stec, Opole 2015, s. 399402, 411-417.

$6 \quad$ K. Łopatecki, "Disciplina militaria” w wojskach Rzeczypospolitej do połowy XVII wieku, Białystok 2012, s. 10 n., zwłaszcza Aneks I i II 
zachowania. Artykuły musiały być przez żołnierzy poznane i zaakceptowane"7 W drugiej połowie XVI w. przekształciły się w zbiory prawa wojskowego, które obowiązywało wszystkich żołnierzy oraz osoby towarzyszące wojsku w trakcie przemarszów i prowadzenia działań wojennych ${ }^{8}$. Do początków XVII w. nabrały rangę swoistych krótkich kodeksów wojskowego prawa karnego obowiązującego także w czasie pokoju, a proces ten zwieńczyło potwierdzenie powagą sejmu Rzeczypospolitej "Artykułów wojskowych hetmańskich” wydanych w 1609 r. Zyskały przez to status prawa publicznego i stały się na długo podstawową wykładnią prawa wojskowego w armii polskiej i litewskiej ${ }^{10}$. Pod tym względem mniejsze znaczenie miały artykuły królewskie, które jak te ustanowione przez Władysława IV dla autoramentu cudzoziemskiego, mogły być uznawane za akty prawne wydane przez króla private authoritate ${ }^{11}$. Dlatego też nie miały mocy obowiązującej wszystkich żołnierzy armii, a tym bardziej ludności cywilnej. Ponadto nie był określony zasięg terytorialny ich stosowania ${ }^{12}$.

W praktyce życia wojskowego w autoramentach cudzoziemskich i korpusach artylerii obu armii Rzeczypospolitej stosowano artykuły królewskie, na pewno te wydane w pierwszych latach rządów przez Władysława IV i Augusta II. Dowodzą tego choćby zbiory prawa wojskowego z połowy XVIII w., w których znalazły się artykuły wojskowe obu tych władców ${ }^{13}$. Pominięto w nich

\section{Ibidem, s. 703.}

8 G. Błaszczyk, Artykuly wojskowe i ich rola dla ustroju sił zbrojnych i prawa wojskowego, [w:] „Czasopismo Prawno-Historyczne" (CzP-H) 1979, t. 2, s. 101-103.

9 S. Kutrzeba, op. cit., s. XIV-XVIII; W. Organiściak, Artykuły wojenne króla Augusta III z 1749 roku, „Z Dziejów Prawa” (ZDP) 2010, t. 3 (11) [Prace Naukowe Uniwersytetu Śląskiego nr 2763], s. 170.

10 Okoliczności powstania artykułów hetmańskich, charakterystyka i ich stosowanie: J. Muszyński, Zagadnienie stużby wojskowej w Artykułach hetmańskich z 1609 r., "Wojskowy Przegląd Prawny” (WPP), 1961, nr 1, s. 110-120; K. Łopatecki, „Disciplina militaria”..., s. 617-637; przedruk S. Kutrzeba, op. cit., s. 176-206; opis: W. Organiściak, Geneza i znaczenie "Artykułów wojennych hetmańskich" z 1609 roku, ZDP 2006, nr 8, s. 69-84.

11 W. Organiściak, Kodeksy wojskowe w Polsce roku 1775, Katowice 2001, s. 52; idem, Artykuły wojenne Augusta III Sasa z 1749 roku..., s. 173.

12 Artykuły cudzoziemskie opracował: K. Łopatecki, Artykuły wojskowe autoramentu cudzoziemskiego Władysława IV - okoliczności powstania i ich charakterystyka, "Zeszyty Prawnicze UKSW" (ZPUKSW) 2011, t. 11, nr 2, s. 235-254; pokazując ich wzorcową treść; określając czas powstania na rok 1633 (prawdopodobnie 6 IX), pierwotnie obowiązywały w regimencie królewskim (1633 r.) w wojskach pieszych i dragonii (bez rajtarii); w 2 połowie XVII w. ich stosowanie zostało rozszerzone na Wielkie Księstwo Litewskie.

13 Artykuły Władysława IV dla oddziałów autoramentu cudzoziemskiego po raz pierwszy zostały wydane drukiem w zbiorze Michała Kazimierza Paca, Wilno 1673, k. K2-M2. Następnie opublikowane w: Artykuly wojenne powaga Rzpltey, królów polskich y hetmanów W. X. Lit. różnymi czasy ustanowione, teraz zaś z rozkazu JO. Xiążęcia Jegomości Michała V. Kazimierza Radziwiłła wojewody Wileńskiego, hetmana W. X. Lit. Przedrukowane, Nieśwież 1754, s. 40-92. Po raz kolejny wydane w poprawionej przez S. Brodowskiego kodyfikacji prawa dla wojska litewskiego, w której zamieszczone zostały też artykuły Władysława IV dla artylerii oraz artykuły wojskowe Augusta II: Artykuły wojenne powaga Rzpltey, królów polskich y hetmanów W. X. Lit. różnymi czasy ustanowione z rozkazu JO. Xiążęcia Jegomości Michała V. Kazimierza Radziwiłła...” (dalej [S. Brodowski], Artykuły wojenne...), Elbląg 1755, s. 35-68 („Artykuły wojsku cudzoziemskiemu ... Władysława IV”), 165-181 („Artykuły Przesławnej Artyleryi ... Władysława IV”), 182-192 („Artykuły Wojskowe” Augusta II). Artykuły Augusta II S. Brodowski opublikował w wydanym dwa lata wcześniej w: Corpus Juris Militaris Polonicum w którym się znaydują Artykuły Woienne Hetmańskie..., Elbląg 1753, s. 450-454. 
natomiast artykuły Augusta III, choć opublikowane one zostały kilka - kilkanaście lat wcześniej w kompendiach prawa wojskowego „radziwiłłowskim” i Samuela Brodowskiego. Rodzi to wątpliwości, co do rangi i mocy obowiązywania artykułów drugiego Wettina w armiach Rzeczypospolitej.

Z dwóch królewskich aktów normatywnych większe znacznie winny mieć Artykuły Wojenne, które August III podpisał w Warszawie 31 VIII 1749 r. ${ }^{14}$ Niewątpliwie ustanowione zostały w celu zastąpienia artykułów wojskowych Augusta II, które jako wydane w 1698 r. $^{15}$, wymagały uzupełnienia i dostosowania do potrzeb armii nieprzeznaczonych do prowadzenia wojny, a pozostających na usługach państwa nastawionego na politykę pokojową. Artykuły Wojenne Augusta III miały więcej paragrafów, które opisywały postawy żołnierzy w trakcie wykonywania zadań związanych ze służą garnizonową. Zmieniono w nich też wymiar kar grożących za część przestępstw i wykroczeń - w większości złagodzono grożące sankcję ${ }^{16}$. Ponadto zamierzeniem Augusta III było, aby akt normatywny obowiązywał wszystkich żołnierzy pozostających w służbie Rzeczypospolitej, w obu autoramentach i korpusach artylerii armii koronnej i litewskiej. Znalazło to swój wyraz w tytule odpisu tych artykułów, który zachował się do dnia dzisiejszego: „Naijłaskawsze Nowo potwierdzone Woienne Artijkułij, dla Wijższech, ij Niskich officerow, ij prostich żołnierzow tak od Infanterijeij iako tez Kawalerijeij, Dragunów ij Artellerijeij od całeij Respubliki"17. Według Wojciecha Organiściaka niewiele z tych zamierzeń wyszło. Rozważając kwestię zakresu terytorialnego obowiązywania artykułów Augusta III stwierdził

14 W. Organiściak, Artykuły wojenne króla Augusta III, „Z Dziejów Prawa”, t. 3 (11), Katowice 2010 [Prace Naukowe Uniwersytetu Śląskiego nr 2763], s. 177-184.

15 Z datacją 22 II 1698 r. „Artykuły Woyskowe, i Rota Przysięgi, na które Naiaśnieyszemu i Naypotężnieyszemu Krolowi Jmci Polskiemu, Augustowi II Panu Naszemu Miłościwemu, y Prześwietniey Rzeczypospolitey Polskiey, wszyscy wobec, w służbę zaciągnieni Zołnierze y Officyerowie, przysiąc y one dotrzymać powinni", bo pod takim tytułem się ukazały, zostały opublikowane w XVIII w. przez S. Brodowskiego najpierw w 1753 r. w: Corpus..., s. 450-454, a następnie w: [S. Brodowski], Artykuly wojenne..., s. 182-192. Wydania te stały się podstawą ich przedrukowania przez S. Kutrzebę, Polskie ustawy $i$ artykuły wojskowe od XV do XVIII wieki, Kraków 1937, s. 292-296. Ta ostatnia praca stanowi od blisko 80 lat wojskowości podstawowe źródło informacji o zabytkach prawa wojskowego doby staropolskiej. Wojciech Organiściak opierając się na dwóch kodeksach prawa wojskowego wydanych w 1723 r. i 1724 r. przez J.CH. Lüniga i T. Fritscha uważa, że August II wydał swoje artykułu blisko 4 miesiące wcześniej, gdyż 1 XI 1697 r. w Krakowie: W. Organiściak, Kodeksy wojskowe..., s. 24 oraz Artykuły wojenne Augusta III Sasa z 1749 roku..., s. 166. Jednak należy zaznaczyć, że w pracy J. Ch. Lünniga, Corpus juris militaris des Heil[igen] Roemischen Reichs, T.1, Lepizig 1723, s. 818 znajduje się jedynie informacja o wydaniu przez Augusta II „Articuls-Brieff” w Krakowie 1 XI 1698 r. Opatrzono nią przedruk artykułów wojskowych Augusta II wydanych w Warszawie 30 XI 1700 r., niemal identycznych z tymi opublikowanymi przez S. Brodowskiego i później S. Kutrzebę, ale z zastąpieniem odwołania do Rzeczypospolitej przez tytuł "Jaśnie oświecony książę elektor Saksonii” (Churf[ürst]1[ich] Durchl[aut] zu Sachsen). J.Ch. Lünnig, op. cit., s. 816-818.

16 W. Organiściak, Artykuły wojenne króla Augusta III..., s. 177-184; S. Kutrzeba, op. cit., s. $292-296$.

17 Cytat za wydaniem artykułów Augusta III przygotowanym przez W. Organiściaka, Artykuły wojenne króla Augusta III..., s. 177. Niestety badacz ten nie dostosował się do wymogów edycji źródeł z doby staropolskiej, co poważnie utrudnia lekturę Artykułów Wojennych, zwłaszcza w obliczu nieodróżniania litery "y” od złożeń liter „yj” czy „,ij”. Karol Łopatecki zmodernizował tytuł aktu normatywnego i podał go w formie „Najłaskawsze nowo potwierdzone wojenne artykuły, dla wyższech i niskich oficerów, i prostych żołnierzów tak od infanterii jako też kawalerii, dragunów i artylerii od całej Respubliki wielce pochwalone”. K. Łopatecki, „Disciplina militaria”..., s. 585. 
co prawda, że obejmował tak Koronę, jak i Litwy ${ }^{18}$. Jednocześnie dostrzegając brak ich przedruku w zbiorach prawa wojskowego z lat pięćdziesiątych XVIII w. i czasów stanisławowskich, stwierdził, że ze względu na „brak większej liczby śladów ich stosowania" nie sposób jednoznacznie rozwikłać problemu obowiązywania Artykułów Wojennych Augusta III w obu armiach Rzeczypospolitej ${ }^{19}$. Uzupełniając wywody tego badacza mogę stwierdzić, że w spuściznach po hetmanach koronnych Janie Klemensie Branickim i Wacławie Rzewuskim nie znalazłem przypadków stosowania tych przepisów w praktyce sądownictwa wojskowego ${ }^{20}$. Nie można więc wykluczyć, że odmówiono im mocy wiążącej, a sprawcami tego byli hetmani Rzeczypospolitej, przede wszystkim głównodowodzący wojskiem koronnym w latach 1733/1735-1751 Józef Potocki, który od początku lat czterdziestych XVIII w. pozostawał w zdecydowanej opozycji do dworu królewskiego ${ }^{21}$.

Te same zastrzeżenia należy zgłosić do obowiązywania artykułów wojskowych Augusta III dla artylerii koronnej. Z ich preambuły wynika, że zostały w kwietniu 1737 r. wydane na prośbę ówczesnego generała artylerii polskiej Zygmunta Adolfa Rybińskiego, który w dokumencie występuje pod powszechnie używanym przez samego generała imieniem Jan („Johanne”) ${ }^{22}$. Opracowane zostały „na wzór” artykułów wojskowych dla artylerii Zygmunta III i Władysława IV. Jeżeli chodzi o pierwszego z tych władców, to nie znamy specjalnych przepisów prawnych opracowanych za jego panowania dla artylerii. Możliwe więc, że chodziło o "Artykuły dla puszkarzy” wydane przez Zygmunta Augusta w Lebedziowie 20 XI 1567 r., a potwierdzone przez Zygmunta III w 1589 $\mathrm{r}^{23}$ Kolejnym aktem normatywnym adresowanym do korpusu artyleryjskiego były Artykuły Przesławnej Artylerii wydane przez Władysława IV w obozie pod Smoleńskiem 6 stycznia 1634 r. Zawierały one zebrane w 24 punktach obowiązki i normy zachowania żołnierzy artylerii, tak w trakcie działań bojowych czy wypełniania obowiązków służbowych w okresie pokoju, jak i w czasie wolnym od służby. Integralną częścią tego aktu normatywnego była rozbudowana rota przysięgi. Autorstwo artykułów wojskowych przypisuje się pułkownikowi Gotthardowi Janowi Platerowi ${ }^{24}$, a zaaprobowane i nieznacznie rozbudowane przez

18 W. Organiściak, Artykuły wojenne Augusta III Sasa z 1749 roku..., s. 172, 175.

19 Ibidem, s. 174-175 (cytat ze s. 174).

20 W przypadku badań nad prawem wojskowym i jego praktycznym zastosowaniem największe znaczenie mają akta wojskowe zebrane w Archiwum Główne Akt Dawnych (AGAD), Archiwum Roskie, Militaria, pudła 4-22 (J. K. Branicki) oraz w ANK, APodh I, II i IV.

$21 \quad$ T. Ciesielski, Armia koronna..., s. 118-120; idem, Działalność wojskowa hetmana wielkiego koronnego Józefa Potockiego i jego kręgu klientalno-rodzinnego, [w:] Władza i prestiż. Magnateria Rzeczypospolitej w XVI-XVIII wieku, red. J. Urwanowicz, E. Dubas-Urwanowicz, P. Guzowski, Białystok 2003, s. 267-273.

22 ANKr, Archiwum Potockich z Krzeszowic, 3209, s. 225-235

23 S. Kutrzeba, op. cit., s. 138-142; K. Łopatecki, „Disciplina militaria”..., s. 557-566.

24 [S. Brodowski], Artykuly wojenne..., s. 178; K. Łopatecki, „Disciplina militaria”..., s. 570, 575-577, 580. 
Władysława IV stały się jednym ze wstępnych elementów przeprowadzonej przez niego reformy artylerii ${ }^{25}$.

Zdaniem K. Łopateckiego „przepisy z lat 1633-1634, mimo pewnych niedociągnięć redakcyjnych, należy ocenić bardzo wysoko na tle tych z 1567 r. Po pierwsze, omawiane artykuły regulowały szerszy zakres spraw. Po drugie, umiejętnie opracowano w nich system kar i nagród - sankcję zaostrzono, rozbudowano katalog przestępstw zagrożonych karą więzienia i wskazano przestępstwa ściągające na winowajcę karę śmierci, którą wcześniej stosowno w wyjątkowych przypadkach. Za najcięższe przestępstwa (...) uznano dezercję oraz zdradę. (...) na uwagę zasługuje również: wyeksponowanie nagród, które w innych artykułach odgrywały marginalną rolę; (...) usankcjonowanie zwyczajów artyleryjskich, ustalenie płacy za wykonywanie dodatkowych usług na rzecz wojska, zapewnienie opieki na wypadek starości i kalectwa, nowa, rozbudowana rota przysiegi, dostosowana $\mathrm{w}$ treści do warunków bojowych"26. Wydanie nowych praw wojskowych, w połączeniu z reformami organizacyjno-finansowymi podniosło dyscyplinę w tej elitarnej formacji sił zbrojnych, co szybko dostrzegła szlachta, która po 1641 r. przestała się interesować dyscypliną w wojskach artyleryjskich ${ }^{27}$. Zapewniło to długie trwanie artykułów artyleryjskich Władysława IV, do których zmiany czy zmodernizowania nie przymierzano się także w czasach Augusta II. Zapewne dopiero po wpływem kompromitującej postawy nie tylko artylerii, ale praktycznie całego wojska Rzeczypospolitej w trakcie tzw. wojny o sukcesję polską (1733-1735), dostrzeżono potrzebę wydania nie tyle całkowicie nowych, co zmodernizowanych artykułów artyleryjskich. Porównując akt normatywny z 1737 r. z tym z 1634 r. trudno nie zauważyć wielu elementów wspólnych, choć niewątpliwe "augustowskie” są znacznie uboższe pod względem literackim. Zawierają jednak zbliżony katalog obowiązków artylerzystów i grożących im kar. Opracowane przez Augusta III rozpoczynały się od wezwania żołnierzy do życia bogobojnego i "przystojnego”, które w tych z 1634 r. znajduje się w art. 3. W tych z 1737 r. dodatkowo obowiązki natury wyznaniowej i obyczajowej zostały poszerzone o stanowcze zakazy nadużywania imienia boskiego, złorzeczenia, bluźnienia, przeklinania, a także bałwochwalstwa, czarów, zabobonów, „zaklinania broni” i sięgania po inne „,czartowskie" praktyki (art. 4 i 5) ${ }^{28}$. W artykułach artyleryjskich 1634 r. ważniejsze od tych praktyk było unikanie sodomii i „życia nieczystego" (art. 3). Kolejne paragrafy zobowiązywały żołnierzy do wierności oraz oddania królowi i

\footnotetext{
$25 \quad$ K. Łopatecki, "Disciplina militaria”,.., s. 583-584.

$26 \quad$ Ibidem, s. 578-579.

27 Ibidem, s. 584.

28 Karanie za czary w wojsku było obce polskiej i litewskiej kulturze prawnej, występowało one natomiast w artykułach wojskowych dla oddziałów ryskich, w tym artylerzystów z 1600 r., oraz autoramencie cudzoziemskim: S. Kutrzeba, op. cit., s. 210; K. Łopatecki, Charakterystyka "miejskich artykułów wojskowych" na przykładzie "Rigischer Artikelsbrieff” z 1600 roku, "Zapiski Historyczne” (ZH), 2013, R. 78, nr 2, s. 28.
} 
Rzeczypospolitej, a także bezwzględnego posłuszeństwa wobec przełożonych i wykonywania wszystkich ich rozkazów (1634 art. 2; 1737 art. 3). Z tą jedynie różnicą, że w artykułach artyleryjskich z 1634 r. wyliczanie przełożonych rozpoczyna się od pułkownika artylerii, a w 1737 r. od generała artylerii koronnej, ale urząd ten został ustanowiony dopiero w 1635 r. W artykułach artyleryjskich z 1634 r. król zapewniał szczególną ochronę całej kadrze dowódczej i wszystkim urzędnikom artylerii wykonującym obowiązki służbowe (art. 26). W obu aktach normatywnych określono warunki zakończenia służby. Było to możliwe tylko po uzyskaniu abszejtu, który zgodnie z przepisami z 1634 r. należało wydać każdemu żołnierzowi mogącemu wykazać się „dostateczną przyczyną”, chęcią poszukania gdzie indziej lepszych warunków służby czy z powodu złego stanu zdrowia (art. 2). W artykułach artyleryjskich z 1737 r. nie określono warunków otrzymania dymisji, a jedynie stwierdzono, że bez jej uzyskania nie wolno było oddalić się z oddziału i podjąć służby w innym regimencie pod groźbą kar grożących za dezercję (art. 26). W obu artykułach wojskowych zakazywano żołnierzom gier, zwłaszcza hazardowych, a także nadużywania alkoholu i pełnienia, gdy znajdowali się pod jego wpływem, służby wartowniczej. W akcie opublikowanym przez Władysława IV zakazywano także pobytu w miejscach, w których organizowano gry hazardowe, opowiadania o swojej służbie w karczmach oraz poniżania, czy gardzenia współtowarzyszami służby (1634 art. 4 i 5, 1737 art. 6 i 7). W artykułach artyleryjskich z 1737 r. surowe kary „na czci, ciele i życiu" groziły za przekazywanie cudzoziemcom i obcym ludziom informacji o stanie artylerii (art. 13). Zakazane pod groźbą kary więzienia (1634 art. 7), a nawet śmierci (1737 art. 8) były kłótnie, bójki, a zwłaszcza pojedynki. Dopilnować tego mieli przełożeni. W obu artykułach dużą wage przywiązywano do należytego wypełniania obowiązków służbowych oraz troski o powierzony sprzęt wojskowy. Jeżeli chodzi o pierwszą kategorię, to szczególną wagę przywiązywano do służby wartowniczej. W artykułach artyleryjskich z 1634 r. żołnierzom nakazano obowiązkowe jej pełnienie przez cały wyznaczony czas aż do zluzowania; niepodmieniania się i wynajmowania zastępców; stawiania się na wartę w stanie nietrzeźwości, a w trakcie jej pełnienia spożywania alkoholu; wpuszczania nieznanych osób do arsenału, na baterie, jak i zezwalanie im na oglądanie, dotykanie i mierzenie dział czy moździerzy (art. 9, 10, 11, 12). W sposób bardzo zwięzły (z wyjątkiem ostatniej powinności) powtórzono to w 1737 r. (art. 15, 16, 24). W obu aktach wprowadzono obowiązek bezzwłocznego przybycia z całym wyposażeniem do arsenału, magazynu lub na wyznaczone miejsce w polu w czasie pożaru, a w 1737 r. także na wypadek innej klęski żywiołowej (1634, art. 20). W prawach wojskowych z 1634 r. sporo przy tym uwagi poświęcono innym niż wartownicze obowiązkom służbowym, gdyż wprowadzono nakaz stawiania się wszystkich żołnierzy rano i wieczorem przed kwaterą dowódcy w celu wysłuchania rozkazów dziennych (art. 15); oraz pozostawanie po zejściu z warty w stałej gotowości do podjęcia służby, także bojowej 
i związanej z obsługą dział. Stawiać się mieli z bronią, ładownicami, lontami i innym sprzętem artyleryjskim (art. 15, 16, 17). Nawet gdy zwolnieni byli od jakichkolwiek obowiązków służbowych, nie mogli bez wiedzy przełożonych oddalać się w dzień od fortecy czy obozu na odległość strzału armatniego (art. 19). Samowolne opuszczenie bez urlopu miejsca pełnienia służby karane miało być zakuciem w kajdany i więzieniem (art. 20). Szczególną gotowość do pełnienia służby i troskę o bezpieczeństwo mieli artylerzyści wykazywać w trakcie obecności króla lub cudzoziemców w arsenale (art. 18). Wszystkim artylerzystom nakazano, aby „pilnie się ćwiczyli w swoich sztukach i naukach i sposabiali się do tego wszystkiego, co po każdym wyciąga jego służba i powinności"29 (art. 33). W artykułach artyleryjskich z 1737 r. od artylerzystów wymagano jedynie umiejętności obsługi dział, zakazując im ładowania i strzelania z nich bez wiedzy i rozkazu przełożonego oficera (art. 11 i 19). W trakcie pełnienia zwykłej, pokojowej służby jedynym obostrzeniem była konieczność przebywania po capstrzyku w swoich gospodach (art. 20). Szczególnym okresem pełnienia służby był czas wojenny. W 1634 r. król, choć przepisy prawne wydane zostały w trakcie walk o Smoleńsk z Rosjanami, poświęcił temu tylko dwa artykuły. Podkreślono w nich, że każde oddalenie się z oddziału, a tym bardziej przejście na stronę nieprzyjaciela będzie karane „na ciele i życiu” (art. 21). Takie same kary groziły za utrzymywanie kontaktów z nieprzyjacielem, a także za niezadenuncjowanie współtowarzyszy szykujących się do zdrady czy podejmujących jakieś podejrzane działania (art. 22). Praktycznie identyczne były postanowienia w tych materiach artykułach artyleryjskich z 1737 r., w których dodano wśród katalogów kar przybicie do szubienicy tabliczki z imieniem nieujętego dezertera (art. 14,21). Surowo karane miało być też porzucenie posterunków ochraniających własny obóz, a nawet spanie w trakcie pełnienia na nich służby (art. 24). Zakazane było udawanie się w trakcie prowadzonych działań bojowych na rabunek i po łupy, ale dozwolone to było „po wygranej sprawie” i za przyzwoleniem dowódców (art. 25). Wiele uwagi w 1737 r. poświęcono należytej trosce o arsenały i prochownie, sprzęt i amunicję artyleryjską, a także broń osobistą. Musiała być starannie czyszczona i konserwowana, zabezpieczona przed uszkodzeniem czy zniszczeniem. O zauważonych uszkodzeniach żołnierze zobowiązani byli bezzwłocznego zameldować przełożonym - gdy byli winni szkody ponosili odpowiedzialność materialną, a w przypadku zniszczenia sprzętu artyleryjskiego groziła im nawet śmierć (art. 9, 10, 12, 19). Stosunkowo lakonicznie i tylko w odniesieniu do sprzętu artyleryjskiego omówiono to w prawach ogłoszonych przez Władysława IV (art. 13), przez co można odnieść wrażenie, że w drugiej ćwierci XVIII w. szczególną bolączką był brak należytej troski o sprzęt artyleryjski. I tak w rzeczywistości było, a artylerzystów służących w Kamieńcu Podolskim, Białej Cerkwi, Okopach Świętej Trójcy tłumaczy fakt, że praktycznie wszystkie działa i moździerze ustawione były na bateriach. W innych zaś

29 S. Kutrzeba, op. cit., s. 230. 
arsenałach, z wyjątkiem Warszawy, pod ich pieczą znajdował się sprzęt zdecydowanie przestarzały, niekompletny, uszkodzony lub wręcz nadający się jedynie na przetopienie (złomowanie) ${ }^{30}$. W artykułach artyleryjskich z 1634 r. pojawiły się natomiast przepisy o obowiązkach cejkwartów (cejgwartów) i fajerwerków (ogniomistrzów). Pierwsi jako gospodarze arsenału mieli pod swoją pieczą klucze do jego pomieszczeń (art. 14). Do zadań fajerwerków należało czyszczenie i mielenie saletry, aby stała się zdatna do produkcji dobrego prochu, a także wykonywanie różnych prac naprawczych $\mathrm{w}$ arsenale. Wykraczało to poza ich obowiązki służbowe i dlatego mieli otrzymywać dodatkową zapłatę w wysokości 24 groszy za każdy przygotowany cetnar saletry oraz 54 grosze tygodniowo za prace wykonane w arsenale (art. 24). Artykuły wojskowe z 1634 r. zawierały też gwarancje dla artylerzystów należycie wywiązujących się ze swoich obowiązków - była to wypłata żołdu co miesiąc lub kwartalnie, wymiana munduru raz do roku (art. 25), a także wolności i przywileje, z których korzystały korpusy artylerii w innych państwach europejskich (zakończenie). Ponadto artylerzyści, którzy odnieśli w trakcie wypełniania obowiązków rany uniemożliwiające im dalsze służbę, mieli otrzymać dożywotnie utrzymanie, a gdyby zdecydowali się opuścić Rzeczpospolitą odprawę („,słuszną nagrodę" - art. 2). W artykule 8 zapowiedziano też, że artylerzyści mogli otrzymać od króla pardon (zapewne za sumienną służbę), który kasował wszystkie popełnione przez nich występki przed podjęciem służby wojskowej. Takich sytuacji nie przewidywały artykuły artyleryjskie z 1737, który nakazywał bezwzględne usuwanie bez dymisji (czyli i odprawy) z artylerii wszystkich żołnierzy, którzy popełnili jakiekolwiek przestępstwa. Jeżeli w grę wchodziły czyny kryminalne (zabójstwo, kradzież, rozbój, a także cudzołóstwo), żołnierz podlegał pod prawo pospolite (art. 23, 30). Takich szczegółowych zapisów regulujących obowiązki i przywileje żołnierzy artylerii nie ma w prawach Augusta III. Jedynie w artykule 34 zagwarantowano im regularne wypłacanie żołdu i lenungu, a także wydawanie munduru i bielizny („przymunderunek”). W kilku przepisach prawnych zawarto natomiast restrykcyjne postanowienia tyczące się obowiązków i zachowania żołnierzy w miejscach stacjonowania, które jak wynika z artykułu 29 obowiązywały ich od chwili odebrania pierwszego lenungu, czyli wyprowiantowania. Od tego momentu nie mogli pozostawać $w$ jakichkolwiek związkach $\mathrm{z}$ kobietami podejrzanej konduity, a gdy chcieli zawrzeć związek małżeński, musieli uzyskać zgodę bezpośredniego przełożonego, potwierdzoną następnie przez generała artylerii (art. 17) ${ }^{31}$. Zadbać musieli o utrzymywanie dobrych relacji z właścicielami domów, w których zostali zakwaterowani, unikać wszelkich „niepoczciwych akcji" oraz szkodzenia osobom zaopatrującym armię w żywność i inne

T. Ciesielski, Armia koronna..., s. 150-198.

31 T. Ciesielski, Rodzina wojskowa w połowie XVIII wieku, [w:] Rodzina i gospodarstwo domowe na ziemiach polskich w XV-XX wieku. Struktury demograficzne, społeczne i gospodarcze, red. C. Kuklo, Warszawa 2008, s. 231-246; K. Łopatecki, Związki małżeńskie i pozamałżeńskie w armii koronnej i litewskiej w XVI $i$ XVII stuleciu - prawo i stan faktyczny, „Miscellanea Historico-Iuridica” (MH-I) 2014, t. 13, z. 2, s. 47-71. 
„,towary” (art. 29, 30, 31). Surowo zakazane było grabienie i niszczenie kościołów, klasztorów, ratuszy, magazynów, młynów, piekarni, kuźni i innych obiektów użyteczności publicznej (art. 27). Za wszystkie wykroczenia groziły surowe kary, od degradacji w przypadku nienależytego wykonywania obowiązków służbowych aż po utratę życia w przypadku zdrady w trakcie wojny, dezercji czy popełnienie przestępstw kryminalnych. W przypadku tych ostatnich nawet uzyskanie pardonu nie skutkowało całkowitym uwolnieniem od kary (art. 32, 33) .

Artykuły artyleryjskie Augusta III były znacznie bardziej dostosowane do realiów służby czasu pokoju niż wydane przez Władysława IV. Jednak nie stały się prawem obowiązującym w wojsku koronnym, o czym świadczy nie tylko brak ich przedruków w zbiorach prawa wojskowego, odpisów w spuściznach archiwalnych komendantów twierdz, dowódców arsenałów czy oddziałów artylerii. Nie zachowały się też żadne przekazy źródłowe świadczące, że zapoznawano z nimi artylerzystów w wojsku koronnym czy litewskim, czy o ich wykorzystywaniu w praktyce sądowniczej. I w ich przypadku należy domniemywać, że do wprowadzenia w życie tej niewielkiej, a potrzebnej reformy prawa wojskowego nie dopuścił hetman wielki koronny Józef Potocki. Choć w 1737 r. był jednym z przywódców stronnictwa pozostającego w sojuszu z dworem królewskim, to jako głównodowodzący armią koronną skwapliwie strzegł zakresu swojej władzy wojskowej, ostro reagując na wszelkie próby jej naruszenia. Jego stosunek do Zygmunta Adolfa Rybińskiego był nieufny od samego momentu jego nominacji na generała artylerii, a w niektórych okresach wręcz wrogi. Nie mogło jednak być inaczej, skoro po nadaniu 9 XII 1735 r. Rybińskiemu urzędu generała artylerii koronnej mówiło się w Warszawie, że August III wybrał go, gdyż „sam chce w artylerii koronnej porządek uczynić”32. Nic więc dziwnego, że Potocki uważnie kontrolował poczynania Rybińskiego, podkreślając jego zależność służbową od siebie. Gdy generał artylerii podejmował działania, które wzbudzały podejrzenia hetmana, ten nie wahał się udzielać mu ostrych reprymend oraz grozić zastosowaniem sankcji karnych i to z całą surowością artykułów wojskowych. W kwietniu 1737 r. pretekstu do tego dostarczyła sprawa kapitana Antoniego Arciszewskiego, który za swoje wykroczenie został, zdaniem Potockiego, zbyt łagodnie ukarany. Hetman zażądał zaostrzenia kary, grożąc Rybińskiemu w liście napisanym w Stanisławowie 27 IV 1737 r., że „mam władzę i potrafię jej zażyć" ${ }^{33}$. Nie można wykluczyć, że artykuły dla artylerii zostały wydane jako reakcja dworu na ten spór hetmana $\mathrm{z}$ generałem artylerii w celu wzmocnienia pozycji tego ostatniego. Niezależnie od motywów ich powstania, nadanie im mocy obowiązującej w wojsku koronnym było dla Józefa Potockiego nie do przyjęcia. Skutecznie przeciwstawił się monarsze, a Rybińskiego zmusił

32 A. F. Cichocki do J. A. Załuskiego, Warszawa 21 XII 1735, [w:] Korespondencja Józefa Andrzeja Załuskiego, wyd. B. S. Kupyść i K. Muszyńska, Warszawa 1968, s. 517; T. Ciesielski, Armia koronna..., s. 148.

33 J. Potocki do Z. A. Rybińskiego, Stanisławów 23 IV 1737, AGAD, Archiwum Publiczne Potockich (APPot), 127, s. 172; T. Ciesielski, Armia koronna..., s. 150. 
latem 1738 r. do uległości. Doszło do tego po ostrej reprymendzie udzielonej przez hetmana generałowi artylerii, gdy ten bez skonsultowania się z nim nakazał przewieźć 6 armat z Kamieńca Podolskiego do Lwowa ${ }^{34}$.

Ukorzenie się Zygmunta Adolfa Rybińskiego zapewne ostatecznie przekreśliło zamiary nadania mocy obowiązującej w wojsku koronnym artykułom artyleryjskim Augusta III, o których szybko zapomniano, jak o każdej nieudanej próbie reformatorskiej. Zwłaszcza, że 12 lat później król podjął kolejną próbę zmiany obowiązującego prawa wojskowego. Jak wynika z tytułów opracowanych w 1749 r. Artykułów Wojennych obowiązywać one miały także w korpusach artylerii. Wraz z ich wydaniem nastąpił „De iure koniec ery funkcjonowania odrębnych artykułów artyleryjskich" ${ }^{35}$. Dyplomy królewskie z 1737 r. wylądowały w archiwach - w 1765 r. w tzw. Archiwum Artylerii Koronnej znajdowała się „kopia artykułów artyleryi koronnej, anno 1737"36. Karol Łopatecki na podstawie tego zapisu w inwentarzu archiwalnym zadał sobie pytanie "Czy mowa tu o kolejnych artykułach artyleryjskich?" I kierując się brakiem wzmianki o nich w pracach Brodowskiego opublikowanych w latach 1753-1754 stwierdził: „Wydaje się to wątpliwe, chodzi raczej o odpis przepisów z 1634 r." ${ }^{37}$.

\section{Aneks}

\section{ARTYKULY WOJSKOWE ARTYLERII KORONNEJ, DREZNO 27 IV 1737}

\section{opracował Tomasz Ciesielski}

W spuściźnie archiwalnej po Potockich z Krzeszowic, przechowywanej obecnie w Archiwum Narodowym w Krakowie, zachował się dyplom królewski z 1737 r. ustanawiający Artykuty Wojskowe Artylerii Koronnej (sygn. 3209, s. 225-235), który niewątpliwe zasługuje na opublikowanie, choć od jego powstania minęło blisko 300 lat i zapewne nigdy nie stał się obowiązującym prawem. Stanowi jednak cenny zabytek polskiego prawa wojskowego zasługujący na wprowadzenie do obiegu naukowego. Tekst źródła został opracowany zgodnie z obowiązującymi zaleceniami wydawniczymi źródeł staropolskich ${ }^{38}$. Przede wszystkim

34 Z. A. Rybiński do J. Potockiego, Warszawa 19 VI 1737; J. Potocki do Z. A. Rybińskiego, Stanisławów 1 i 10 VII 1737, AGAD, APPot, 127, s. 633-634, 645; T. Ciesielski, Armia koronna..., s. 150.

35 K. Łopatecki, „Disciplina militaria”..., s. 585.

36 S. Skrzyński, Inwentarz archiwum artylerii koronnej z $1765 r$., „Studia i Materiały do Historii Wojskowości" 1960, t. 6, cz. 1, s. 278-279.

${ }_{37}$ K. Łopatecki, „Disciplina militaria”..., s. 585.

38 Przede wszystkim: Instrukcja wydawnicza dla źódeł historycznych od XVI do połowy XIX wieku, red. K. Lepszy, Wrocław 1953. 
zadbałem o zachowanie brzmienia języka źródła, ale starając się zastosować, w miarę możności, współczesną pisownię i interpunkcję. W przypadku tej ostatniej zakres ingerencji jest dość spory, gdyż nie zawsze znaki interpunkcyjne zostały w źródle zastosowanie zgodnie ze współczesnymi regułami, a niekiedy też ich brakuje. Przestawienie lub wprowadzenie tych znaków było konieczne, aby ułatwić zrozumienie poszczególnych zdań, nie zmieniając jednak sensu przekazu tekstu. Skróty zostały rozwinięte, a zaznaczono to przez umieszczenie nawiasu kwadratowego. W ten sam sposób zaznaczono wprowadzenie brakujących w wyrazie liter. Spójnik "y" zastąpiłem przez „,i”. Zmodernizowałem

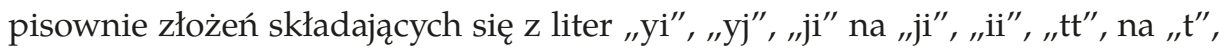
a tam gdzie to było potrzebne, zamieniłem litery s, a i e na ś, ą i ę. Występujące w oryginalnym zapisie „bydź" zastąpiłem przez „byćc; a „cięszkim” przez ,ciężkim".

Augustus III Dei Gratia Rex Poloniae, Magnus Dux Lithuaniae, Russiae, Prussiae, Masoviae, Samogitiae, Kyoviae, Volhyniae, Podoliae, Poldachie, Livoniae, Smolensciae, Severiae, Czerniechoviaeque, Nec Non Haereditarius Dux Saxoniae et Principes Elector ${ }^{1}$

Significamus praesentibus Litteris Nostris quorum interest universis et singulis. Supplicatum Nobis esse a Generoso sincere Nobis dilecto Johanne Rybiński², Artilleriae sive Rei tormentariae Nostrae et Regni Generali Pra[e]fecto ut subsequentes Articulos Militares Artilleriae Nobis exhibitos ad exemplum Serenissimerum Antecessorum Nostrorum Regum Poloniae Sigismundi IIItti et Vladislai IV to approbare confirmamre et ratificare dignaremur; quorum Articulorum tenor de Verbo ad Verbum est talis ${ }^{3}$

ARTYKUŁ PIERWSZY. Ponieważ wszelkie Błogosławieństwo, szczęście i powodzenie dobre, szczególnie i jedynie od samego Najdobrotliwszego Boga

August III Z Bożej Łaski Król Polski, Wielki Książę Litewski, Ruski, Pruski, Mazowiecki, Żmudzki, Kijowski, Wołyński, Podolski, Podlaski, Inflancki, Smoleński, Siewierski i Czernichowski, Jak Też Książę Saksonii i Książe Elektor

2 Zygmunt Adolf Rybiński, który objął ten urząd 1 XII 1735 r. po Janie Klemensie Branickim (otrzymał buławę polną koronną) i dowodził artylerią do śmierci 29 VIII 1746. W latach 1714-1724 generałem artylerii koronnej był inny Rybiński, brat Zygmunta Adolfa, Jakub Zygmunt: Urzędnicy centralni i nadworni Polski XIV-XVIII wieku. Spisy, red. A. Gąsiorowski, oprac. K. Chłapowski, S. Ciara, Ł. Kądziela, T. Nowakowski, E. Opaliński, G. Rutkowska, T. Zielińska, Kórnik 1992, nr 107 i 110, s. 38.

3 Oznajmiamy niniejszym Pismem Naszym, które do wszystkich i do każdego zainteresowanego jest (adresowanego wszem i wobec). Upraszani byliśmy przez szlachetnego szczerze przez Nas umiłowanego Jana Rybińskiego, artylerii czyli ludwisarza Naszego i Królestwa Generalnego Zwierzchnika, żeby następujące Artykuły Wojskowe Artylerii Naszej ogłosić na wzór Najjaśniejszych Poprzedników Naszych Zygmunta III-ego i Władysława IV-ego, aprobować, utwierdzić i ratyfikować autorytetem naszym (godnością naszą), których Artykułów brzmienie (zawartość) słowo w słowo jest takie (taka): 
pochodzi zaczym każdy ober i unter officier ${ }^{4}$, tudzież i prosty artyllerysta ${ }^{5}$ i wszyscy puszkarze ${ }^{6}$, i każdy pod artyllerią Koronną służący powinien nade wszystko bogobojnie i przystojnie żyć i sprawować się.

ARTYKUŁ WTÓRY. Przy tym J. K. M. Augustowi i Najjaśniejszej Rzeczypospolitej we wszystkim wiernie, ochotnie, poczciwie i szczerze służyć, wszelkie dobro i commodo ${ }^{7} \mathrm{w}$ każdej okazji, według możności usilnie pomnażać, a zaś wszelkim szkodom, stratom i niebezpieczeństwom ze wszystkich sił zabiegać i od nich ochraniać, i jeżeliby co takowego do wiadomości jego przyszło, bez najmniejszego omieszkania przełożonym swoim objawić i opowiedzieć powinien.

ARTYKUŁ TRZECI. Teraźniejszemu Generałowi Artylerii Koronnej, albo [s. 228] któryby onemu w tym urzędzie kiedykolwiek sukcedował ${ }^{8}$ i wszystkim przełożonym ober i unter officierom, aby każdy powinien i należyty respekt, i posłuszeństwo pełnił, wydane od nich rozkazy i zakazy punktualnie wykonywał i wszystko, cokolwiek tylko bądź w fortecach, bądź w cekhauzach ${ }^{9}$ lub obozie według okoliczności czasu i potrzeby ordynować będą, durante tempore $^{10}$ służby swojej jako najlepiej, tak jak każdemu poczciwość kochającemu i doskonałemu artylleryście należy, we wszystkim bez żadnego sprzeciwienia się obserwował, a kto by przeciwko temu wykroczył, takowy pro per juro ma być poczytany, przed sąd stawiony i według trybu wojskowego za uznaniem karany.

ARTYKUŁ CZWARTY. Żaden nie powinien Najwyższego Boga zapominać, a tym mniej Świętego Imienia i słowa Jego brać nadaremno, albo bluźnić, ale od przeklinania i swawolnej mowy powinien się wstrzymywać pod karą na ciele i życiu.

ARTYKU€ PIĄTY. Wszelkie bałwochwalstwa, czary, zabobony, zamawiania strzelby i inne podejrzane czartowskie kunszta, przy których Najświętsze Imię Boskie nadaremnie brane, albo lżone bywa mają nade wszystko zakazane.

ARTYKU€ SZÓSTY. Każdy pod artylerią służący, tak konny, jako i pieszy, czy to feierwerk ${ }^{11}$, czyli puszkarz, albo jaki inny rzemieś[1]nik i wszystkie do artylerii należące osoby, bądź kto chce, będący czy to w fortecach, czy w obozie, powinny się wstrzymywać od nienależytego grania i kosterstwa ${ }^{12}$, przez które

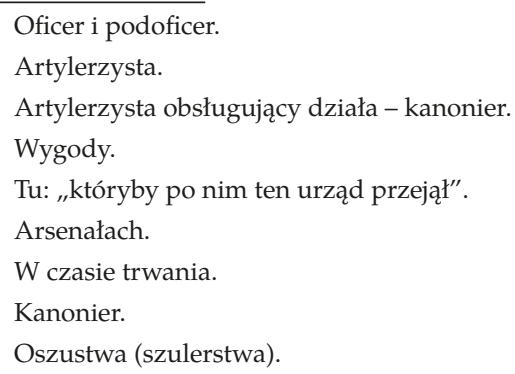


często nieszczęścia pochodzą, kto by zaś przeciw temu zakazaniu wykroczył ma być więzieniem, albo według okoliczności surowszą karą karany.

ARTYKUŁ SIÓDMY. Zbyteczne pijaństwo, osobliwie będącym na warcie, $\mathrm{w}$ fortecach, cekhauzach ${ }^{13}$ et laboratoriis ${ }^{14}$, także $\mathrm{w}$ obozie na bateriach ${ }^{15}$ wcale się zakazuje, a który przeciw wykroczy, ma być serio karany, ile gdy takowy, który w pijaństwie excess ${ }^{16}$ popełni, tym się wymawiać nie może, ale tym bardziej dlatego, że przez pijaństwo [s. 229] zgrzeszył, surowej karze podlegać będzie.

ARTYKUŁ ÓSMY. Wszelkie zwady, swary, kłótnie, niepotrzebne hałasy, za łby rwanie, passowania ${ }^{17}$ i pojedynki na każdym miejscu wszystkim prostym artyllerystom, jako też i unter officierom absolute ${ }^{18}$ zakazuje się pod karaniem na ciele i na życiu. In quantum by się zaś przytrafiło, żeby między dwiema lub trzema wszczęła się jaka niezgoda, tedy zaraz powinno być o tym doniesiono officierowi i według jego zdania i dyspozycji ma być rzecz rozprawiona.

ARTYKUŁ DZIEWIĄTY. Żaden nie powinien powierzonej sobie broni, munderunku ${ }^{19}$ i innych requizytów ${ }^{20}$ bez potrzeby zażywać, pasować, łamać lub inszym jakim sposobem w nich szkodę uczynić, dopieroż [s]przedać, zastawić lub przegrać, albo w inszy jaki nienależyty sposób stracić, pod ciężkim aresztem i restytucją z własnych swoich pieniędzy zgubionej rzeczy. A jeżeliby który nie miał sposobu do restytucji, ma być onemu co miesiąc proporcjonalnie odciągnione z jego traktamentu póty, póki rzeczy zgubionej nie będzie bonifikacja.

ARTYKUŁ DZIESIĄTY. Każdy powinien to, cokolwiek z amunicji, prochów, ołowiu i innych do artylerii należących materiałów powierzono mu będzie, z jak największą pilnością i staraniem konserwować i przypilnować, a jeżeliby się przez nie dozór i z okazji czyjej stała jaka szkoda, za to odpowiadać, i według circumstancji ${ }^{21}$ rzeczy, karania spodziewać się ma.

ARTYKUŁ JEDENASTY. Żaden nie powinien powierzonej mu armaty, moździerzy nabijaniem przesadzać, bez potrzeby i wiadomości przełożonego officiera swego ognia nie dawać, owszem to wszystko, do czego kto komenderowany będzie i powinien, aby przy armacie żadnego nie było omieszkania, kto by zaś przeciw temu wykroczył na honorze, ciele i na życiu ma być karany.

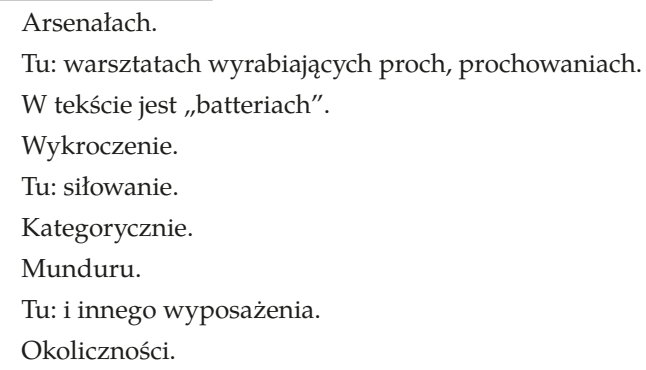


ARTYKUŁ DWUNASTY. Wszyscy generaliter ${ }^{22}$ przy cekhauzach znajdujący się kommenderujący ${ }^{23}$ ober officierowie, osobliwe kommendę mając, także unter officyerowie i prości [s. 230] pilne staranie o tym mieć powinni, aby armaty, strzelby ${ }^{24}$, amunicje i inne do artylerii należące instrumenta ${ }^{25}$, armatury ${ }^{26}$ i rzeczy należycie dozierane czysto, polerownie i w dobrym porządku utrzymywane były. A jeżeliby się to stać nie miało, tedy bez odwłoki Przełożonemu officierowi doniesiono ma być. A gdyby przez którego niedozór szkoda i niebezpieczeństwo stało się, takowy za to odpowiadać i na życiu karany być ma.

ARTYKUŁ TRZYNASTY. Żaden z officierów, unter officierów i prostych, tak cekhauzów ${ }^{27}$, jako i samej artyllerii sytuacji i dyspozycji, obcym i zagranicznym ludziom objawić nie ma i opisywać, ale to wszystko w zamilczeniu wiernie u siebie zachować, a kto by przeciwko temu wykroczył, ma być na czci, ciele i życiu karany.

ARTYKUŁ CZTERNASTY. Z nieprzyjacielem, aby żaden nie miewał kommunikacji, rokowania i korrespondencji, ani żądnego innego porozumienia, a jeszcze tym mniej, aby nieprzyjacielskiego znaczku nie nosił, inaczej takowy każdy na czci i życiu swoim karany będzie.

ARTYKUŁ PIĘTNASTY. Bez wiadomości kommendę mającego officiera, aby żadnych obcych i nieznajomych osób do cekhauzów nie wprowadzano, ani onych wpuszczano, także i na bateriach blisko armat i moździerzów chodzić i onych zapałów, ani samych rur dotykać się i mierzyć żadną miarą nie pozwalano. A kto by się ważył to czynić, aby takowego zaraz w areszt wziąć, i o tym officierowu kommendę mającemu do dalszych disquizycji ${ }^{28}$ donieść, pod karą noszenia kul i pod więzieniem.

ARTYKUŁ SZESNASTY. Żaden nie powinien sobie straży i warty, ani innej jakiejkolwiek powinności, do której kommenderowany będzie, opuścić póki tejże służbie i powinności swojej za dosyć nie uczyni, a który przeciwko temu postąpi, takowy przed sąd stawiony i według okoliczności rzeczy, na honorze, ciele i życiu karany być ma.

ARTYKUŁ SIED[E]MNASTY. Swywolnych i podejrzanych białogłów albo wszetecznic i konkubin, aby żaden do artyllerii przy sobie nie chował, ani w obozie, ani w kwaterach i onych z sobą nie [s. 231] woził, alias ${ }^{29}$ należytej podlegać będzie karze. Jeżeliby zaś który z artyllerzystów w poczciwy stan małżeński

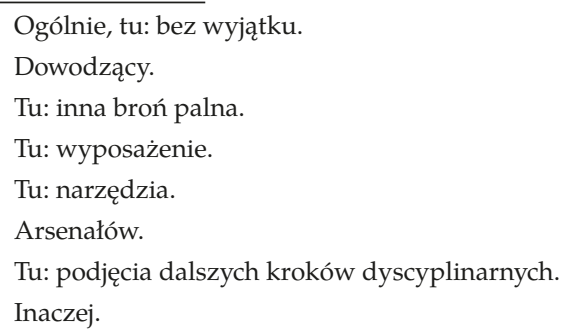


wstąpić chciał, tedy powinien to wprzódy samemu przełożonemu officierowi opowiedzieć i o pozwolenie upraszać. A za tym jeżeli to postanowienie będzie dla niego pożyteczne, onemu in scripto konsens ${ }^{30}$ od Generała Artyllerii ma być dany.

ARTYKUŁ OS[IE]MNASTY. Kiedy się jaka trwoga, pożar albo burza przytrafi, lub w takowych miejscach, gdzie się cekhauz, albo też magazyn znajduje lub też w polu, czy to w dzień, czyli w nocy, tedy powinni wszyscy z bronią, lontami, cyntrutami ${ }^{31}$ i innemi do artyllerii należącemi instrumentami zaraz przed gospodę officiera kommendę mającego stawać i tam dalszego oczekiwać ordynansu, jeżeliby zaś który albo przez niedbalstwo tam się nie stawił, albo też bez pozwolenia stamtąd odszedł, to takowy za nieposłusznego uznany i na przykład innym surowo ma być karany.

ARTYKUŁ DZIEWIĘTNASTY. Każdy który będzie komenderowany czy to w pole, czy to do fortecy do dania ognia z armat, albo też do rzucania moździerza, takowy powinien według należytej proporcji i kunsztu artylerycznego, tak jako się najlepiej nauczył wyrychtować i palić oraz jeżeliby potrzeba tego wyciągała, aby wiedział znowu wyładować. Kiedy zaś który powierzoną mu armatę lub moździerz znajdzie w czym szkodliwie nadpsowany, powinien zaraz officierowi swojemu o tym oznajmić i pokazać pod karaniem według uznania jego niedbalstwa i okoliczności rzeczy.

ARTYKUŁ DWUDZIESTY. Żaden nie ma w nocy z swojej absentować się gospody, ale zaraz po wybitym capstrichu ${ }^{32} \mathrm{w}$ niej się znajdować, w czym, gdy kto wykroczy, płazowaniem albo noszeniem kul karany będzie.

ARTYKUŁ DWUDZIESTY PIERWSZY. Nie powinien żaden bez wyraźnie na piśmie otrzymanego pozwolenia absentować się od swojej kompaniej i uchodzić, bo takowy, który by to uczynił i kryjomym sposobem od artyllerii uciekł, w gospodzie nie nocował, albo w cale do nieprzyjaciela przebiegł, albo z pola uciekł, według trybu wojskowego, [s. 232] gdy będzie złapany, bez żadnego miłosierdzia ma być obwieszony. A jeżeliby osoby jego nie można było dostać, tedy przez edykt cytowany ${ }^{33}$, pro invindicabili capite ${ }^{34}$ uznany, szelmowany i imię jego przez kata do szubienicy ma być przybite.

ARTYKUŁ DWUDZIESTY WTÓRY. Wszyscy artyllerzystowie generalnie powinni się od buntowania i rozruchów, jak najpilniej wstrzymywać i żądnych schadzek bez wiadomości officierów nie miewać pod karaniem na ciele i na

\footnotetext{
Pisemna zgoda.

Zapałami armatnimi?

Capstrzyku.

Tu: w edykcie wymieniony z imienia.

Tu: za takiego, którego zabicie nie będzie karane.
} 
życiu, a ci którzy by się buntować i rebeliezować 35 ważyli, a osobliwie authores ${ }^{36}$ i namówcy, bez żadnego pardonu rozstrzelani będą.

ARTYKUŁ DWUDZIESTY TRZECI. Wszelkie insze pospolite, a nieszczególnie żołnierskie przestępstwa, jako to: złodziejstwo, zabójstwo, cudzołóstwo, rozboje i tym podobne mają być według prawa pospolitego w Koronie Polskiej sądzone i karane.

ARTYKUŁ DWUDZIESTY CZWARTY. Nie powinien także żaden powierzonej sobie poczty albo straży porzucić, ani na niej dać się śpiącym znaleźć, a kto przeciwko temu wykroczy, ma być sądzony i według trybu wojskowego karany. Delinquent ${ }^{37}$ zaś na szyldwachu bez żadnej klemencji gardło tracić.

ARTYKUŁ DWUDZIESTY PIĄTY. Podczas wojny, gdy fortece albo obozy nieprzyjacielskie odbierane będą, nie ma się żaden od artyllerii na łup i rabunki udawać, ale tylko to czynić, co mu rozkazano będzie. A pierwej do niczego się nie odważać aż po wygranej sprawie, ubezpieczenie stanie, albo mu na to od officierów kommendę mających pozwolenie dane będzie, a to pod karą gardła.

ARTYKU€ DWUDZIESTY SZÓSTY. Żaden w służbie pod artyllerią zostający, pierwej póki formalnego nie otrzyma abszejtetu ${ }^{38}$ pod inszy regiment albo $\mathrm{w}$ inszą służbę zaciągiwać się nie powinien, a kto by to uczynił, takowy jako krzywoprzysięzca i zbieg sądzony i karany być ma.

ARTYKUŁ DWUDZIESTY SIÓDMY. Kościoły, klasztory, ratusze, magazyny, młyny, piekarnie, kuźnie i inne do pospolitego używania potrzebne domy [s. 233] i miejsca warują się, aby onym swywolnie żadnej nikt nie czynił szkody i ruiny, inaczej contra veniens ${ }^{39}$ surowo karany będzie.

ARTYKUŁ DWUDZIESTY ÓSMY. Powinien także każdy w naznaczonej onemu gospodzie z gospodarzem i jego ludźmi uczciwie i zgodnie się obchodzić, a kto by się inaczej sprawował, ma być według uznania okoliczności rzeczy aresztem, albo jeszcze i surowiej karany.

ARTYKUŁ DWUDZIESTY DZIEWIĄTY. Wszyscy generaliter, którzy w przyszły czas pod artyllerią zawerbowani będą, jak prędko pierwszy lenung ${ }^{40}$ odbiorą, choćby się jeszcze i przysięgą nieobowiązali, przecież według tych artykułów sprawować się powinni i obowiązani są, a in casu contrawencjii ${ }^{41}$, karom $\mathrm{w}$ nich opisanym podlegać mają

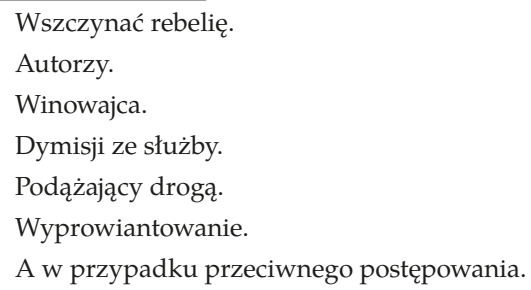


ARTYKUŁ TRZYDZIESTY. Żaden, który jaką niepoczciwą popełnił akcją, albo był w katowskich ręku, nie ma być pod artyllerią cierpiany, ale bez abszejtu od niej odegnany.

ARTYKUŁ TRZYDZIESTY PIERWSZY. Ludziom prowiant i towary przywożącym nikt nie powinien czynić krzywdy, inaczej za to surowej karze podpadać będzie.

ARTYKUŁ TRZYDZIESTY WTÓRY. In quantum by ktokolwiek służby swojej według powinności szarży swej należycie nie obserwował i onej nie pełnił, takowy według circumstancji rzeczy degradowany, kassowany, albo jeżeli występek będzie wielki, na czci i życiu ma być karany.

ARTYKUŁ TRZYDZIESTY TRZECI. Jeżeliby się przytrafiło, że który unter officier albo puszkarz główne jakie delictum ${ }^{42}$ popełni, dla którego by życie stracić musiał, jednakże z ważnych jakich przyczyn był pardonowany i uwolniony, tedy takowy miasto tracenia gardła, degradacją i bieganiem przez rózgi, tak jako to mu według zważenia okoliczności rzeczy przysądzono będzie, karany być ma.

ARTYKUŁ TRZYDZIESTY CZWARTY. Wzajemnie zaś każdemu Artyllerzyście obiecuje i deklaruje się, że mu jego naznaczony lenung i traktament ${ }^{43}$, także munderunek $^{44}$ i przymunderunek ${ }^{45}$, zawsze jako się rozporządziła i postanowił punktualnie płacony i dawany będzie.

[s. 234]

Te wszystkie wzwyż opisane ARTYKUŁY ordynuje i rozkazuje Naj[j]aśniejszy Król Je[go] M[oś]ć, aby w całej Artyllerii Koronnej publikowane i na zawsze obserwowane były, których contenta ${ }^{46}$ wszyscy pod artyllerią zostający officierowie, unter officierowie i prości we wszystkim wykonać według rozkazu i zakazu onych sprawować się powinni, dlaczego też z nich każdy przysięgą obowiązany być powinien, w ten tudzież następujący sposób.

Formula Juramenti ${ }^{47}$. Wszystko to, co mi tu teraz wzwyż opisanych Artykułach wyrażonemi słowy przeczytano, chcę zawsze statecznie i nieprzełomnie ${ }^{48}$ dotrzymać i temu wszystkiemu za dosyć uczynić albo w nie dotrzymaniu tego postanowionemu w nich karaniu podlegać. Tak mi Panie BOŻE W TRÓJCY ŚWIETEJ JEDYNY dopomóż i niewinna męka CHRYSTUSA PANA, Amen.

\footnotetext{
Przestępstwo.

3 Żołd.

44 Mundur.

45 Bieliznę.

46 Zawartość, tu: postanowienia.

47 Rota Przysięgi.

$48 \quad$ Niezłomnie.
} 
Cui quidem Supplication benigne annuentes, Artilleriamq[ue] Nostram et Reipublicae circa bonum ordinem et exactam disciplinam conservaturi. Nos Augustus III Rex Poloniae, praenominatos Articulos hic insertos omnis et singulos, in omnibus corum punctis, clausulis, conditionibus, singulisque et universis contentis, quantum Juris ratio et usus eorundem Articulorum paritur auctoritate Nostras Regias, approbamus, confirmamus et ratificamus eos robur debitae firmitatis habere volentes. In cujus rei fidem praesentes Manum Nostras subscriptas, Sigillo Regni communiri jussimus. Datum Dresdae Die XXVIIIa Mensis Aprilis Anno Domini MDCCXXXVIImo Regni vero Nostri IVto Anno

Augustus Rex ${ }^{49}$

Joannes Wolski Subdapifer Districtus et Notarius Castrensis Chencinensis S[acr]ae N[ostr]ae M[aies]t[a]tis Sigilli Regni Secretarius ${ }^{50}$

Articuli Militaris Artilleriae Regni ${ }^{51}$

\section{Bibliografia}

Archiwum Główne Akt Dawnych w Warszawie, Archiwum Potockich, 127.

Archiwum Narodowe w Krakowie, Archiwum Podhoreckie, I, 120; II, 8, 32, 52, 172, $175,183,186,229$.

Archiwum Narodowe w Krakowie, Archiwum Potockich z Krzeszowic, 3209

Archiwum Państwowe w Poznaniu, Archiwum Antoniego Kossowskiego, 10.

Biblioteka Książąt Czartoryskich w Krakowie, 2630.

Artykuły wojenne powaga Rzpltey, królów polskich y hetmanów W. X. Lit. różnymi czasy ustanowione, teraz zaś z rozkazu JO. Xiążęcia Jegomości Michała V. Kazimierza

${ }_{49} \quad$ Do której oczywiście prośby łaskawie przychyliwszy, i Artylerii Naszej i Rzeczypospolitej wokół dobrego porządku dobra publicznego i właściwej dyscypliny zachowania. My August III Król Polski, przesławne Artykuły tu wprowadzone wszystkim i każdemu z osobna, we wszystkich punktach, klauzulach, warunkach, i pojedynczej i całkowitej zawartości, jako Prawo sądowe i praktykowane tak samo na równi z artykułami powagą (władzą) Naszą Królewską aprobujemy, umacniamy i ratyfikujemy ich siłą obowiązującą stanowczo chcemy mieć. Na wiarę czego obecnie Ręką Naszą podpisujemy, Pieczęcią Królewską przywieszoną potwierdzamy. Dane w Dreźnie dnia 28-go miesiąca kwietnia Roku Pańskiego 1737-go Panowania zaś Naszego 4-go roku, August Król.

50 Jan Wolski podstoli powiatu i pisarz grodzki chęciński, Świętego Naszego Majestatu Sekretarz Pieczęci Królewskiej. Jan Wolski był sekretarzem pieczęci wielkiej koronnej i pisarzem grodzkim chęcińskim. Urząd podstolego chęcińskiego sprawował od 19 VII 1736 r. do 31 X 1746 r., gdy awansował na stolnika chęcińskiego. Zmarł przed 20 VIII 1748 r., gdy stolnikostwo chęcińskie zostało nadane „po śmierci poprzednika”, Stefanowi Konarskiemu, Urzędnicy województwa sandomierskiego XVI-XVIII wieku. Spisy, red. A. Gąsiorowski, oprac. K. Chłapowski, A. Falniowska-Gradowska, Kórnik 1993, nr 41, s. 29 i nr 81 , s. 33.

51 Artykuły wojskowe artylerii koronnej. 
Radziwiłła wojewody Wileńskiego, hetmana W. X. Lit. Przedrukowane, Nieśwież 1754 .

Artykuły wojenne powaga Rzpltey, królów polskich y hetmanów W. X. Lit. różnymi czasy ustanowione z rozkazu JO. Xiążęcia Jegomości Michała V. Kazimierza Radziwiłła..., wyd. S. Brodowski, Elbląg 1755.

Corpus Juris Militaris Polonicum w którym się znayduja Artykuły Woienne Hetmańskie..., oprac. S. Brodowski, Elbląg 1753.

Korespondencja Józefa Andrzeja Załuskiego, wyd. B.S. Kupyść i K. Muszyńska, Warszawa 1968

Kutrzebę S., Polskie ustawy i artykuły wojskowe od XV do XVIII wieki, Kraków 1937.

Lünniga J. Ch., Corpus juris militaris des Heil[igen] Roemischen Reichs, t.1, Lepizig 1723.

Błaszczyk G., Artykuły wojskowe i ich rola dla ustroju sit zbrojnych i prawa wojskowego, „Czasopismo Prawno-Historyczne” 1979, t. 2.

Ciesielski T., Armia koronna w czasach Augusta III, Warszawa 2009.

Ciesielski T., Armia Wielkiego Księstwa Litewskiego w latach 1717-1775, [w:] Studia z dziejów Wielkiego Księstwa Litewskiego (XVI-XVIII wieku), red. S. Górzyński, M. Nagielski, Warszawa 2014.

Ciesielski T., Działalność wojskowa hetmana wielkiego koronnego Józefa Potockiego i jego kregu klientalno-rodzinnego, [w:] Władza i prestiż. Magnateria Rzeczypospolitej w XVI-XVIII wieku, red. J. Urwanowicz, E. Dubas-Urwanowicz, P. Guzowski, Białystok 2003.

Ciesielski T., Rodzina wojskowa w połowie XVIII wieku, [w:] Rodzina i gospodarstwo domowe na ziemiach polskich w XV-XX wieku. Struktury demograficzne, społeczne i gospodarcze, red. C. Kuklo, Warszawa 2008.

Ciesielski T., Samuel Brodowski - kodyfikator prawa wojskowego w czasach panowania Augusta III, [w:] Historia testis temporum, lux veritatis vita memoriae, nuntia vetustatis. Księga Jublieuszowa dedykowana Profesorowi Włodzimierzowi Kaczorowskiemu, red. E. Kozerska, M. Maciejewski, P. Stec, Opole 2015.

Ciesielski T., Wojsko litewskie w latach 1698-1709, [w:] Wojny pótnocne w XVI-XVIII wieku, red. B. Dybaś, A. Ziemlewska, Torun 2007.

Ciesielski T., Sachs R., Breslau als Lieferant für die königlich polnische Armee, [w:] Amator Scientiae. Festchrift für Dr. Peter Ohr, oprac. R. Sachs, Breslau 2003.

W. Dziewanowski, Zarys dziejów uzbrojenia w Polsce, Warszawa 1935.

Łopatecki K., Artykuły wojskowe autoramentu cudzoziemskiego Władysława IV - okoliczności powstania i ich charakterystyka, "Zeszyty Prawnicze UKSW” 2011, t. 11, nr 2.

Łopatecki K., Charakterystyka "miejskich artykułów wojskowych” na przykładzie "Rigischer Artikelsbrieff” z 1600 roku, "Zapiski Historyczne” 2013, t. 78, nr 2.

Łopatecki K., „Disciplina militaria” w wojskach Rzeczypospolitej do połowy XVII wieku, Białystok 2012. 
Łopatecki K., Związki mał̇̇eńskie i pozamałżeńskie w armii koronnej i litewskiej w XVI i XVII stuleciu - prawo i stan faktyczny, „Miscellanea Historico-Iuridica” 2014, t. 13, z. 2.

Muszyński J., Zagadnienie służby wojskowej w Artykułach hetmańskich z 1609 r., "Wojskowy Przegląd Prawny" 1961, nr 1.

Organiściak W., Artykuły wojenne króla Augusta III, „ZZ Dziejów Prawa” 2010, t. 3 (11), [Prace Naukowe Uniwersytetu Śląskiego nr 2763].

Organiściak W., Artykuły wojenne króla Augusta III z 1749 roku, „Z Dziejów Prawa”, 2010, t. 3 (11), [Prace Naukowe Uniwersytetu Śląskiego nr 2763].

Organiściak W., Geneza i znaczenie "Artykułów wojennych hetmańskich" z 1609 roku, „Z Dziejów Prawa” 2006, t. 8.

Organiściak W., Kodeksy wojskowe w Polsce roku 1775, Katowice 2001,

Rakutis V., Lietuvos kariuomenès organizacija reglamentuojantys dokumentai 1717-1775 m., „Karo archyvas”, t. 18, Vilnius 2003.

Siciński M., Umundurowanie armii Wielkiego Księstwa Litewskiego w okresie panowania Augusta II i Augusta III Wettinów oraz panowania Stanisława Augusta do czasów reform Sejmu Wielkiego 1717-1791, „Studia do dziejów dawnego uzbrojenia i ubioru wojskowego", cz. 12, Kraków 2011.

Skrzyński S., Inwentarz archiwum artylerii koronnej z 1765 r., „Studia i Materiały do Historii Wojskowości" 1960, t. 6, cz. 1.

Urzędnicy województwa sandomierskiego XVI-XVIII wieku. Spisy, red. A. Gąsiorowski, oprac. K. Chłapowski, A. Falniowska-Gradowska, Kórnik 1993.

Wagner M., Zmiany w uzbrojeniu wojsk polskich na początku XVIII wieku, [w:] Technika a wojna X-XX w., red. P. Matusek, J. Piłatowicz, Siedlce 2000.

Wimmer J., Wojsko Rzeczypospolitej w dobie wojny pótnocnej, Warszawa 1956. 